\title{
Mast cells in collagen diseases
}

\author{
Naoya Mikita*, Yutaka Inaba, Takashi Yoshimasu, Nobuo Kanazawa, Fukumi Furukawa \\ Department of Dermatology, Wakayama Medical University, Wakayama-shi, Wakayama, Japan
}

\begin{abstract}
Mast cells are involved in many immune reactions and diseases through 1) the expressions of several receptors, 2) productions of various mediators such as histamine, cytokines, and chemokines, 3) direct interactions with immune cells. Besides allergic diseases, the involvement of mast cells has been also investigated in autoimmune diseases such as bullous pemphigoid, rheumatoid arthritis, and multiple sclerosis. Moreover, several studies reported the involvement of mast cells in collagen diseases. In this article, we review recent findings about the role of mast cells especially in systemic lupus erythematosus and systemic sclerosis. In these diseases, mast cells seem to be involved in local inflammation and tissue damage in the targeted organ or local immunosuppression rather than the development of autoimmunity including production of autoantibodies.
\end{abstract}

Keywords: mast cells; systemic lupus erythematosus; systemic sclerosis

\section{ARTICLE INFO}

Received: July 12, 2019

Accepted: August 8, 2019

Available online: August 20, 2019

*CORRESPONDING AUTHOR

Naoya Mikita. Department of Dermatology, Wakayama Medical

University, Wakayama-shi, Wakayama, 641-0012, Japan;

naoya@wakayama-med.ac.jp

\section{CITATION}

Mikita N, Inaba Y, Yoshimasu T, et al. Mast cells in collagen diseases. Trends Immunother 2019; 3(2): 69-75. doi: 10.24294/ti.v3.i2.96.

\section{COPYRIGHT}

Copyright $(\mathcal{C} 2019$ by author(s) and EnPress Publisher LLC. This work is licensed under the Creative Commons Attribution-NonCommercial 4.0 International License (CC BY-NC 4.0). http://creativecommons.org/licenses/ by $/ 4.0 /$

\section{Introduction}

Mast cells are hematopoietic cells which have characteristic secretary granules in their cytoplasm ${ }^{[1]}$. Mast cells generally distribute in host-environment interface sites such as skin and mucosal tissues of digestive and respiratory tracts. In these tissues, mast cells response to various pathogens ${ }^{[2]}$. Mast cells play important roles in the defense against some parasitic and bacterial infections. In response to various allergens, mast cells degranulate their secretary granules including histamine, and induce immediate type hypersensitivity and Th2 immune response. Furthermore, mast cells also play important roles in tissue remodeling and fibrosis ${ }^{[1]}$. Due to these diverse functions, the involvement of mast cells has been reported in various diseases including allergic diseases, malignant tumors ${ }^{[3]}$ and autoimmune diseases ${ }^{[4-6]}$. In this review, we summarize current knowledge about the role of mast cells in collagen diseases.

\section{Mast cells in autoimmune diseases}

Mast cells express several receptors on their cell surface. High-affinity $\operatorname{IgE}$ receptor (FceRI) is a well-known receptor that binds specific IgE for various allergens. Allergen stimuli cause crosslinking of FceRI-bound IgE, and induce allergic reactions by degranulation of their cytoplasmic granules. KIT with tyrosine kinase activity is important for mast cell maturation and proliferation. Furthermore, mast cells also express toll-like receptors which recognize pathogen-associated molecular patterns, Fc $\gamma$ RI and Fc $\gamma$ RIII for IgG, and complement receptors for $\mathrm{C} 3 \mathrm{a}$ and $\mathrm{C} 5 \mathrm{a}^{[7,8]}$. The production of various autoantibodies and activation of complement system are key events in many autoimmune diseases. Therefore, expressions of receptors for these components implicate the involvement of mast cells in collagen diseases.

Additionally, mast cells release many types of mediator with or without degranulation. In addition to chemical mediators such as histamine, protease, and lipid mediators, mast cells also produce and release various cytokines (e.g. TNF- $\alpha$, IL-4, IL-5, IL-10, and TGF- $\beta$ ), and chemokines such as CCL2 and $\mathrm{CXCL8}^{[9,10]}$. 
Moreover, mast cells directly interact with various immunocompetent cells through some ligands and costimulatory molecules ${ }^{[5]}$. For example, following antigen stimulation, OX40L on mast cells contributes to $\mathrm{T}$ cell activation through interaction with OX40 on $\mathrm{T}$ cells ${ }^{[11,12]}$. Inversely, OX40 on regulatory $\mathrm{T}$ cells (Tregs) has been reported to inhibit degranulation of mast cells and allergic reaction through interaction with OX40L on mast cells ${ }^{[13]}$. Moreover, mast cells with PD-1 expression directly contact with immature dendritic cells (DCs) with PD-L1 expression, and induce tolerogenic indoleamne-2,3-deoxoygenase expressing DC ${ }^{[14]}$.

Besides these diverse functions of mast cells, recent studies have shown their anti-inflammatory and tolerogenic effects through the production of antiinflammatory cytokine such as IL-10 and TGF- $\beta$ and direct interaction with Tregs and DCs.

On the basis of these diverse immunological effects, the involvement of mast cells has been reported in autoimmune diseases and malignancies. Direct data clarifying their involvement have been reported in several autoimmune diseases such as bullous pemphigoid, rheumatoid arthritis, and multiple sclerosis in human and experimental model ${ }^{[4-6]}$. In rheumatoid arthritis patients, an increased number of mast cells and degranulated mast cells were observed in synovial tissue, and mast cell-derived mediators were shown in synovial fluid ${ }^{[15]}$. In a rheumatoid arthritis model mice, $\mathrm{K} / \mathrm{B} \times \mathrm{N}$ mice, administration of their seruminduced arthritis in control mice, but did not induce arthritis in mast cell-deficient $K i t^{W / W-V}$ mice ${ }^{[16]}$. Some reports proposed the importance of Fc $\gamma$ RIII on mast cells $s^{[17]}$, IL-1 production by mast cells ${ }^{[18]}$, and synovial membrane-derived IL-33 with the IL-33 receptor (ST2) on mast cells ${ }^{[19]}$ in rheumatoid arthritis model. Though in most of these earlier studies, KITdependent mast cell-deficient mice were studied, these mice have immunological abnormalities other than mast cell deficiency. Recently, KIT-independent mice with specific mast cell-deficiency and fewer other immunologic abnormalities have been frequently studied by applying the gene recombination technique targeting a gene specifically expressed by mast cells $^{[20]}$. In the experiment using autoimmune disease models prepared with these genetically modified mice, mast cell deficiency did not influence the disease in antibody-mediated rheumatoid arthritis or T cellmediated experimental autoimmune encephalomyelitis model ${ }^{[21]}$, but it is necessary to investigate whether similar findings are obtained in humans and other model mice.
Compared with the diseases described above, knowledge of the role of mast cells in the other collagen diseases is limited. The roles of mast cells in systemic lupus erythematosus (SLE), systemic sclerosis ( $\mathrm{SSc}$ ), dermatomyositis ${ }^{[22,23]}$, and Sjögren's syndrome ${ }^{[24]}$ have been reported. The roles of mast cells in SLE and SSc are described below.

\section{Mast cells in systemic lupus erythematosus}

SLE is the major collagen disease, which affects diverse organs including kidney, skin and central nervous system. The individual susceptibilities and environmental factors are involved in the development of SLE. Multiple organ damages are closely associated with loss of tolerance and characteristic autoantibody production. This abnormality in immune system results from defective clearance of immune complexes and biological waste, nucleic acid sensing, and interferon production pathway. Various immune cells such as T cells, B cells, dendritic cells and neutrophils are the major cell types involved in SLE. The involvement of mast cells in SLE has been investigated mainly for renal lesions (Table 1). In normal human kidney, only a few mast cells are present preferentially in the interstitial space ${ }^{[25]}$. In lupus nephritis, the number of mast cells increases also in the renal tubule-interstitial area ${ }^{[26]}$. The number of renal mast cells is correlated with renal fibrosis development ${ }^{[27]}$ and differed between classes of lupus nephritis ${ }^{[26]}$. In pristine-induced experimental lupus nephritis model with mast celldeficient $K_{i t}{ }^{W W-V}$ mice, the development of humoral autoimmunity, such as hypergammaglobulinemia and autoantibodies, was comparable to their wildtype counterparts ${ }^{[28]}$. However, in the absence of mast cell, diffuse proliferative glomerulonephritis was more frequently observed compared to wildtype mice. These findings indicated that mast cells were dispensable in the development of humoral autoimmunity, but had limited inhibitory effects for lupus nephritis in this study.

Further investigations are still required for this issue. Clear mechanism and signaling by which mast cells caused lupus nephritis have not been elucidated. Firstly, the involvement of mast cells may not be specific for autoimmune renal disease. Because besides lupus nephritis, the involvement of mast cells in renal inflammation and fibrosis has been reported in various kidney diseases including diabetic nephropathy ${ }^{[29]}$. Secondarily, some studies in human and mice showed no correlation between mast cell and lupus nephritis. In human, no clear correlation was observed between the number of mast cells and 
Table 1. The involvement of mast cells in SLE.

\begin{tabular}{|c|c|c|c|c|c|c|}
\hline Species & Lupus model & $\begin{array}{c}\text { MC } \\
\text { depletion }\end{array}$ & $\begin{array}{l}\text { Role of mast } \\
\text { cell }\end{array}$ & Organ & Findings & References \\
\hline \multirow{5}{*}{ Human } & \multirow{5}{*}{-} & \multirow{5}{*}{-} & \multirow{5}{*}{ Not defined } & \multirow{4}{*}{ Kidney } & $\begin{array}{l}\text { The number of MCs increased in } \\
\text { tubule-interstitial area of LN. }\end{array}$ & \multirow{2}{*}{ [26] } \\
\hline & & & & & $\begin{array}{l}\text { The number of MCs correlated with } \\
\text { the classes of LN. }\end{array}$ & \\
\hline & & & & & $\begin{array}{l}\text { The number of MCs correlated with } \\
\text { renal fibrosis in LN. }\end{array}$ & {$[27]$} \\
\hline & & & & & $\begin{array}{l}\text { The number of MCs did not correlate } \\
\text { with the severity of LN. }\end{array}$ & {$[30]$} \\
\hline & & & & Skin & $\begin{array}{l}\text { MCs preferentially infiltrated } \\
\text { in reticular dermis and peri- } \\
\text { pilosebaceous in CLE }\end{array}$ & {$[32]$} \\
\hline \multirow{9}{*}{ Mouse } & \multirow{2}{*}{$\begin{array}{l}\text { Pristine- } \\
\text { induced }\end{array}$} & \multirow[b]{2}{*}{$K i t^{W / W-V}$} & Suppressive & Kidney & $\begin{array}{l}\text { MCs deficiency increases the } \\
\text { severity of lupus nephritis partially. }\end{array}$ & \multirow[b]{2}{*}{ [28] } \\
\hline & & & No effect & Humoral immunity & $\begin{array}{l}\text { MCs deficiency has no effect on } \\
\text { hypergammaglobulinemia and } \\
\text { autoantibodies. }\end{array}$ & \\
\hline & \multirow{2}{*}{$\begin{array}{l}\text { Lyn }^{-/-} \\
\text {spontaneous } \\
\text { SLE model }\end{array}$} & \multirow{2}{*}{$K i t^{W-s h / W-s h}$} & \multirow{2}{*}{ No effect } & Kidney & $\begin{array}{l}\text { MCs deficiency has no effect on } \\
\text { lupus nephritis. }\end{array}$ & \multirow{2}{*}[31]{} \\
\hline & & & & Humoral immunity & $\begin{array}{l}\text { MCs deficiency has no effect on } \\
\text { autoantibodies and ANA. }\end{array}$ & \\
\hline & \multirow{3}{*}{$\begin{array}{l}\text { MRL/lpr } \\
\text { spontaneous } \\
\text { SLE model }\end{array}$} & \multirow{3}{*}{$K i t^{W-s h / W-s h}$} & Suppressive & Skin & $\begin{array}{l}\text { MCs suppress the development of } \\
\text { skin lesions. }\end{array}$ & \multirow{3}{*}[35]{} \\
\hline & & & Promotive & Kidney & $\begin{array}{l}\text { MCs exacebrated the degree of } \\
\text { proteinuria. }\end{array}$ & \\
\hline & & & Various & Others & $\begin{array}{l}\text { MCs improved survival rate, but } \\
\text { exacebrated serum ds-DNA antibody } \\
\text { level. }\end{array}$ & \\
\hline & \multirow{2}{*}{$\begin{array}{l}\text { B6/lpr } \\
\text { spontaneous } \\
\text { SLE model }\end{array}$} & \multirow[b]{2}{*}{$K i t^{W-s h / W-s h}$} & \multirow[b]{2}{*}{ No effect } & Kidney & $\begin{array}{l}\text { MCs exacebrated the degree of } \\
\text { proteinuria }\end{array}$ & \multirow[b]{2}{*}[36]{} \\
\hline & & & & Humoral immunity & $\begin{array}{l}\text { MCs improve survival rate, but } \\
\text { exacebrated serum ds-DNA antibody } \\
\text { level. }\end{array}$ & \\
\hline
\end{tabular}

Abbreviation: MC: mast cell; LN: lupus nephritis; SLE: systemic lupus erythematosus; ANA: antinuclear antibodies

lupus nephritis severity ${ }^{[30]}$. Src family protein kinase Lyn-deficient mice develop a strong and constitutive Th2 skewing in early life and an autoimmune disease similar to SLE such as production of autoantibodies and lupus-like nephritis in late life. Lyn $^{-/-}$mice deficient in mast cells, $\mathrm{Kit}^{W-s h / W-s h}$; $\mathrm{Lyn}^{-/-}$mice, exhibited comparable severity of lupus nephritis to those in $\mathrm{Lyn}^{-/-}$mice, so lupus-like nephritis was independent of mast cells in $\mathrm{Lyn}^{-/ 2}$ mice ${ }^{[31]}$. In this study, basophils activated by IgE autoantibodies promoted autoantibody production and resulted in lupus-like nephritis.

Skin is exposed to several external agents including pathogens and allergens. Skin is the resident tissue of mast cells, which involved in the cutaneous immunity and diseases. Most of the collagen diseases including SLE also affects skin, but the role of mast cells in skin lesions of lupus patients remains unclear. Thus, we have investigated the role of mast cells in LE, especially focused on the skin lesions. In skin lesions of lupus patients, mast cells abundantly infiltrated mainly the reticular layer of the dermis and around pilosebaceous $^{[32]}$. Moreover, we used MRL/lpr mice as SLE model to investigate lupus skin lesions. MRL/lpr mice are characterized by dysregulated apoptosis due to homozygous $l p r$ mutation in the Fas gene. MRL/lpr mice produce autoantibodies including anti-nuclear antibodies and anti-ds DNA antibodies. These mice develop lupus nephritis and lupus dermatitis-like skin lesions with immune complexes deposition. Lupus dermatitis-like skin lesions in MRL/lpr mice exhibit immunoglobulin deposition in the epidermis-dermis boundary similar to human cutaneous lupus erythematosus, infiltration of many mast cells in the dermis ${ }^{[33]}$ and abnormal histamine metabolism ${ }^{[34]}$. These findings implicate 
the involvement of mast cell in the skin lesions of MRL/lpr mice. Hence, we generated MRL/lpr mice deficient in mast cells, MRL/lpr-Kit ${ }^{W-s h / W-s h}$ mice, and analyzed autoimmune features and symptoms ${ }^{[35]}$. MRL/lpr-Kit ${ }^{W-s h / W-s h}$ mice also developed lupus dermatitis-like skin lesions similar to those in control MRL/lpr mice with mast cells. Histologically, the degree of infiltrating inflammatory cells such as $\mathrm{T}$ cell, macrophage, and neutrophils were comparable among MRL/lpr-Kit ${ }^{W-s h / W-s h}$ and control MRL/lpr mice. However, skin lesions in MRL/lpr-Kit ${ }^{W-s h / W-s h}$ mice occurred earlier, and their age-matched severity scores were higher than those in control MRL/lpr mice. Moreover, MRL/lpr-Kit $t^{W-s h / W-s h}$ mice showed higher mRNA expression of various inflammatory cytokines such as IL-1 $\alpha$, IL-2, IL-4, IL-10, IL-33 and TGF- $\beta$ in the dorsal skin. Systemically, survival rate, serum anti-ds-DNA antibodies levels and proteinuria in MRL/lpr-Kit ${ }^{W-s h / W-s h}$ mice were lower than those in control MRL/lpr mice. These results indicated that mast cells played some protective roles in LE-like autoimmune symptoms, especially skin lesions and except for survival rate, of MRL/lpr mice.

Nevertheless, van Nieuwenhuijze et al. reported the inconsistent results concerning the role of mast cells in $\mathrm{SLE}^{[36]}$. They used lupus C57B16(B6) $)^{\mathrm{lpr} / \mathrm{pr}}$ mice as lupus model, which exhibit lymphoproliferation, production of autoantibodies, and lupus-like nephritis, but their phonotype is somewhat milder than MRL/lpr. B6 ${ }^{1 \mathrm{pr} / \mathrm{pr}}-{ }_{-} \mathrm{Kit}^{W-\mathrm{sh} / W \text {-sh }}$ mice did not change autoantibody production, proteinuria, the composition of $\mathrm{T}$ and $\mathrm{B}$ cell or autoimmune pathology, except for minor findings such as enhanced splenomegaly and reduced IL-4 production by $\mathrm{CD}^{+} \mathrm{T}$ cell. They concluded that mast cell deficiency did not affect lpr-induced systemic autoimmunity similar to SLE. As SLE patients in human are relatively heterogeneous group, the different results by mice strains may result from genetic background. Anyway, most studies could not indicate the effect on the level of autoantibody. Mast cells involve in local inflammation and tissue damage in the targeted organ rather than the development of autoimmunity including production of autoantibodies.

\section{Mast cells in systemic sclerosis}

SSc is another autoimmune connective tissue disease characterized by tissue fibrosis and microangiopathy. SSc affects many internal organs such as the gastrointestinal tract, lungs, kidneys, and heart. Skin symptoms include scleroderma by skin fibrosis, digital ulcer and Raynaud's phenomenon by microanigopathy. These skin symptoms generally appear early in clinical course and are important as diagnostic criteria. Mast cells are closely associated with fibroblasts involved in tissue fibrosis. Moreover, mast cells produce and release mediators such as TGF- $\beta$ and tryptase, which promote tissue fibrosis. The involvement of mast cells has been investigated in several lung, kidney, and heart diseases with tissue fibrosis. Some studies also investigated the role of mast cells in SSc characterized by tissue fibrosis. In SSc patients, mast cells significantly increase in skin lesions of the forearm and fingers ${ }^{[37]}$, and have also been reported to be one of the main sources of TGF $-\beta^{[38]}$ (Table 2). Tyrosine kinase inhibitor, imatinib mesylate, which inhibits the downstream of TGF- $\beta$ and PDGF signaling, candidate for the treatment of $\mathrm{SSc}^{[39,40]}$. Imatinib mesylate also inhibits the growth of cells with KIT receptor. Mast cells also express KIT receptor, so imatinib may have partially effect on mast cells in the treatment for SSc. Moreover, some reports described SSc cases associated mastocytosis, which is the proliferative disease in the mast cell compartment ${ }^{[41,42]}$.

In SSc model mice, bleomycin-induced scleroderma model ${ }^{[43]}$ and tight skin mice ${ }^{[44]}$, mast cells increase in the skin, similarly to those in humans. Moreover, chymase inhibitor alleviated skin fibrosis in tight skin mice ${ }^{[45]}$. However, in the bleomycininduced scleroderma experiments with mast celldeficient $K i t^{W / W-V}$ mice ${ }^{[46]}$ and gene-modified Mcpt5Cre/iDTR mice ${ }^{[47]}$ scleroderma was induced regardless of the presence or absence of mast cells. These findings suggest that the involvement of mast cells is limited, and further investigation using different models is necessary.

\section{Conclusion}

The involvement of mast cells in collagen diseases, especially SLE and SSc, has been investigated, but evidence is still insufficient and controversial. Taken together, mast cells involve in local inflammation and tissue damage in the targeted organ or local immunosuppression rather than the development of autoimmunity including production of autoantibodies.

Though corticosteroids and immune-suppressive agents are still therapeutic mainstay for various autoimmune diseases, side effects of these agents are occasionally problematic. New insights into pathogenesis of collagen diseases have contributed to new targeted therapy, such as B-cell targeted therapy for SLE or SSc ${ }^{[48,49]}$. There are no drugs solely targeted mast cells, but some therapeutic agents suppress the function of mast cells. As mentioned above, some pharmacological agents associated mast cells are effective in human and mouse collagen diseases. 
Table 2. The involvement of mast cells in SSc.

\begin{tabular}{|c|c|c|c|c|c|c|}
\hline Species & SSc model & MC depletion & Role of mast cell & Organ & Findings & References \\
\hline \multirow[t]{2}{*}{ Human } & \multirow[t]{2}{*}{-} & \multirow[t]{2}{*}{-} & Not defined & \multirow[t]{2}{*}{ Skin } & $\begin{array}{l}\text { Dermal MC density in fingers } \\
\text { correlated with severity of skin } \\
\text { sclerosis. }\end{array}$ & [37] \\
\hline & & & Promotive & & Skin MCs are a source of TGF- $\beta$. & {$[38]$} \\
\hline \multirow{5}{*}{ Mouse } & \multirow[b]{2}{*}{ Bleomycin-induced } & - & Not defined & Skin & $\begin{array}{l}\text { The number of dermal MCs } \\
\text { gradulally increased as the skin } \\
\text { sclerotic changes developed. }\end{array}$ & [46] \\
\hline & & $K i t^{W / W-V}$ & No effect & Skin & $\begin{array}{l}\text { The MC deficiency did not affect } \\
\text { the development of skin fibrosis } \\
\text { but the onset of skin fibrosis was } \\
\text { delayed in mice without MCs. }\end{array}$ & [43] \\
\hline & \multirow[t]{2}{*}{ Tight skin mouse } & $K i t^{W / W-V}$ & \multirow[t]{2}{*}{ Promotive } & \multirow[t]{2}{*}{ Skin } & $\begin{array}{l}\text { The number of cutaneous MC } \\
\text { was correlated with development } \\
\text { of fibrosis in old mice. }\end{array}$ & {$[44]$} \\
\hline & & - & & & $\begin{array}{l}\text { Chymase inhibitor attenuated } \\
\text { fibrous proliferation. }\end{array}$ & {$[45]$} \\
\hline & Bleomycin-induced & Mcpt5Cre/iDtR & No effect & Skin & $\begin{array}{l}\text { The MC deficiency did not affect } \\
\text { the development of skin fibrosis. }\end{array}$ & [47] \\
\hline
\end{tabular}

Abbreviation: MC: mast cell; SSc: systemic sclerosis; TGF- $\beta$ : transforming growth factor- $\beta$

Through KIT receptors, imatinib may exert some beneficial effects on mast cells for SSc treatment. The effectiveness of chymase inhibitor for SSc model mice is prospective data for human SSc treatment. Moreover, further knowledge of mast cell involvement in collagen disease may lead to new treatment targeting mast cells ${ }^{[50]}$.

\section{Conflict of interest}

The authors declare no potential conflict of interest with respect to the research, authorship, and/or publication of this article.

\section{References}

1. Wernersson S, Pejler G. Mast cell secretory granules: Armed for battle. Nat Rev Immunol 2014; 14(7): 478-494. doi: 10.1038/nri3690.

2. Abraham SN, St John AL. Mast cell-orchestrated immunity to pathogens. Nat Rev Immunol 2010; 10(6): 440-452. doi: 10.1038/nri2782.

3. Varricchi G, Galdiero MR, Loffredo S, et al. Are mast cells MASTers in cancer? Front Immunol 2017; 8: 424. doi: 10.3389/fimmu.2017.00424.

4. Benoist C, Mathis D. Mast cells in autoimmune disease. Nature 2002; 420(6917): 875-878. doi: 10.1038/nature01324.

5. Sayed BA, Christy A, Quirion MR, et al. The master switch: The role of mast cells in autoimmunity and tolerance. Annu Rev Immunol 2008; 26: 705-739. doi: 10.1146/annurev.immunol.26.02 1607.090320.
6. Yu X, Kasprick A, Petersen F. Revisiting the role of mast cells in autoimmunity. Autoimmun Rev 2015; 14(9): 751-759. doi: 10.1016/j.autrev.2015.04.008.

7. $\mathrm{Yu}$ Y, Blokhuis BR, Garssen J, et al. Non-IgE mediated mast cell activation. Eur J Pharmacol 2016; 778: 33-43. doi: 10.1016/j.ejphar.2015.07.01 7.

8. Ali H. Regulation of human mast cell and basophil function by anaphylatoxins $\mathrm{C} 3 \mathrm{a}$ and $\mathrm{C} 5 \mathrm{a}$. Immunol Lett 2010; 128(1): 36-45. doi: 10.1016/ j.imlet.2009.10.007.

9. Cardamone C, Parente R, Feo GD, et al. Mast cells as effector cells of innate immunity and regulators of adaptive immunity. Immunol Lett 2016; 178: 10-14. doi: 10.1016/j.imlet.2016.07.003.

10. Metz M, Maurer M. Mast cells - key effector cells in immune responses. Trends Immunol 2007; 28(5): 234-241. doi:10.1016/j.it.2007.03.003.

11. Bulfone-Paus S, Bahri R. Mast cells as regulators of T cell responses. Front Immunol 2015; 6: 394. doi: 10.3389/fimmu.2015.00394.

12. Nakae S, Suto H, Iikura M, et al. Mast cells enhance $\mathrm{T}$ cell activation: Importance of mast cell costimulatory molecules and secreted TNF. J Immunol 2006; 176(4): 2238-2248. doi:10.4049/ jimmunol.176.4.2238.

13. Gri G, Piconese S, Frossi B, et al. $\mathrm{CD} 4^{+} \mathrm{CD} 25^{+}$ regulatory $\mathrm{T}$ cells suppress mast cell degranulation and allergic responses through OX40-OX40L interaction. Immunity 2008; 29(5): 771-781. doi: 10.1016/j.immuni.2008.08.018.

14. Rodrigues CP, Ferreira AC, Pinho MP, et al. Tolerogenic $\mathrm{IDO}^{+}$dendritic cells are induced by PD-1-expressing mast cells. Front Immunol 2016; 7: 9. doi: 10.3389/fimmu.2016.00009. 
15. Nigrovic PA, Lee DM. Mast cells in autoantibody responses and arthritis. In: Chadwick DJ, Goode J (editors). Mast cells and basophils: Development, activation and roles in allergic/autoimmune disease: Novartis Foundation Symposium 271. Chichester, UK: John Wiley \& Sons, Ltd; 2005. p. 200-209. doi: 10.1002/9780470033449.ch17.

16. Lee DM, Friend DS, Gurish MF, et al. Mast cells: A cellular link between autoantibodies and inflammatory arthritis. Science 2002; 297(5587): 1689-1692. doi: 10.1126/science. 1073176.

17. Corr M, Crain B. The role of Fc $\gamma R$ signaling in the $\mathrm{K} / \mathrm{B} \times \mathrm{N}$ serum transfer model of arthritis. J Immunol 2002; 169(11): 6604-6609. doi: 10.4049/ jimmunol.169.11.6604.

18. Nigrovic PA, Binstadt BA, Monach PA, et al. Mast cells contribute to initiation of autoantibodymediated arthritis via IL-1. Proc Natl Acad Sci USA 2007; 104(7): 2325-2330. doi: 10.1073/pnas. 0610852103.

19. Xu D, Jiang HR, Li Y, et al. IL-33 exacerbates autoantibody-induced arthritis. J Immunol 2010; 184(5): 2620-2626. doi: 10.4049/jimmunol.090268 5.

20. Rodewald HR, Feyerabend TB. Widespread immunological functions of mast cells: Fact or fiction? Immunity 2012; 37(1): 13-24. doi: 10.1016/j.immu ni.2012.07.007.

21. Feyerabend TB, Weiser A, Tietz A, et al. Cremediated cell ablation contests mast cell contribution in models of antibody- and T cell-mediated autoimmunity. Immunity 2011; 35(5): 832-844. doi: 10.1016/j.immuni.2011.09.015.

22. Yokota M, Suzuki K, Tokoyoda K, et al. Roles of mast cells in the pathogenesis of inflammatory myopathy. Arthritis Res Ther 2014; 16(2): R72. doi: 10.1186/ar4512.

23. Shrestha S, Wershil B, Sarwark JF, et al. Lesional and nonlesional skin from patients with untreated juvenile dermatomyositis displays increased numbers of mast cells and mature plasmacytoid dendritic cells. Arthritis Rheum 2010; 62(9): 28132822. doi: 10.1002/art.27529.

24. Konttinen YT, Hietanen J, Virtanen I, et al. Mast cell derangement in salivary glands in patients with Sjögren's syndrome. Rheumatol Int 2000; 19(4): 141-147. doi: 10.1007/s002960050118.

25. Blank U, Essig M, Scandiuzzi L, et al. Mast cells and inflammatory kidney disease. Immunol Rev 2007; 217: 79-95. doi: 10.1111/j.1600-065X.2007. 00503.x.

26. Kaczmarczyk K, Kosalka J, Soja J, et al. Renal interstitial mast cell counts differ across classes of proliferative lupus nephritis. Folia Histochem Cytobiol 2014; 52(3): 218-224. doi: 10.5603/FHC. 2014.0025.

27. Danilewicz M, Wagrowska-Danilewicz M. Quantitative analysis of interstitial mast cells in lupus and non-lupus membranous glomerulopathy. Pol J Pathol 2001; 52(4): 211-217.
28. Lin L, Gerth AJ, Peng SL. Susceptibility of mast cell-deficient $\mathrm{W} / \mathrm{Wv}$ mice to pristane-induced experimental lupus nephritis. Immunol Lett 2004; 91(2-3): 93-97. doi: 10.1016/j.imlet.2003.11.014.

29. Madjene LC, Pons M, Danelli L, et al. Mast cells in renal inflammation and fibrosis: Lessons learnt from animal studies. Mol Immunol 2015; 63(1): 86-93. doi: 10.1016/j.molimm.2014.03.002.

30. Ravinal RC, Costa RS, Coimbra TM, et al. Mast cells, TGF- $\beta 1$ and myofibroblasts expression in lupus nephritis outcome. Lupus 2005; 14(10): 814-821. doi: 10.1191/0961203305lu2188oa.

31. Charles N, Hardwick D, Daugas E, et al. Basophils and the T helper 2 environment can promote the development of lupus nephritis. Nat Med 2010; 16(6): 701-707. doi: 10.1038/nm.2159.

32. Uede M, Nakamura $\mathrm{Y}$, Yamamoto $\mathrm{Y}$, et al. No differences in number and distribution of dermal mast cells between acute and chronic cutaneous lupus erythematosus. Autoimmune Dis Ther Approach 2014; 2: 109. doi: 10.14437/2378-63371-109.

33. Furukawa F, Tanaka H, Sekita K, et al. Dermatopathological studies on skin lesions of MRL mice. Arch Dermatol Res 1984; 276(3): 186-194. doi: 10.1007/BF00414018.

34. Tachibana $\mathrm{T}$, Furukawa $\mathrm{F}$, Taniguchi $\mathrm{S}$, et al. Histamine metabolism in skin of MRL/1 mice. Arch Dermatol Res 1985; 278(1): 57-60. doi: 10.1007/ BF00412497.

35. Inaba Y, Kanazawa N, Yoshimasu T, et al. Severer lupus erythematosus-like skin lesions in MRL/lpr mice with homozygous $\mathrm{Kit}^{\text {wsh }{ }^{\text {wsh }}}$ mutation. Mod Rheumatol 2017; 11: 1-8. doi: 10.1080/14397595.2017.1341591.

36. van Nieuwenhuijze AE, Cauwe $\mathrm{B}$, Klatt $\mathrm{D}$, et al. Lpr-induced systemic autoimmunity is unaffected by mast cell deficiency. Immunol Cell Biol 2015; 93(10): 841-848. doi: 10.1038/icb.2015.49.

37. Yukawa S, Yamaoka K, Sawamukai N, et al. Dermal mast cell density in fingers reflects severity of skin sclerosis in systemic sclerosis. Mod Rheumatol 2013; 23(6): 1151-1157. doi: 10.1007/ s10165-012-0813-8.

38. Hügle T, Hogan V, White KE, et al. Mast cells are a source of transforming growth factor $\beta$ in systemic sclerosis. Arthritis Rheum 2011; 63(3): 795-799. doi: 10.1002/art.30190.

39. Fraticelli P, Gabrielli B, Pomponio G, et al. Lowdose oral imatinib in the treatment of systemic sclerosis interstitial lung disease unresponsive to cyclophosphamide: A phase II pilot study. Arthritis Res Ther 2014; 16(4): R144. doi: 10.1186/ar4606.

40. Gordon J, Udeh U, Doobay K, et al. Imatinib mesylate (Gleevec ${ }^{\mathrm{TM}}$ ) in the treatment of diffuse cutaneous systemic sclerosis: Results of a 24-month open label, extension phase, single-centre trial. Clin Exp Rheumatol 2014; 32(6 Suppl 86): S189S193.

41. Bagnato G, Roberts WN, Sciortino D, et al. Mastocytosis and systemic sclerosis: A clinical 
association. Clin Mol Allergy 2016; 14: 13. doi: 10.1186/s12948-016-0050-3.

42. Frigui M, Dupin N, Carlotti A, et al. Telangiectasic mastocytosis with systemic sclerosis. Presse Med 2013; 42(5): 902-904. doi: 10.1016/j.lpm.2012.10. 014.

43. Yamamoto T, Takagawa S, Katayama I, et al. Animal model of sclerotic skin. I: Local injections of bleomycin induce sclerotic skin mimicking scleroderma. J Invest Dermatol 1999; 112(4): 456462. doi: 10.1046/j.1523-1747.1999.00528.x.

44. Everett ET, Pablos JL, Harley RA, et al. The role of mast cells in the development of skin fibrosis in tight-skin mutant mice. Comp Biochem Physiol A Physiol 1995; 110(2): 159-165. doi: 10.1016/03009629(94)00127-F.

45. Shiota N, Kakizoe E, Shimoura K, et al. Effect of mast cell chymase inhibitor on the development of scleroderma in tight-skin mice. Br J Pharmacol 2005; 145(4): 424-431. doi: 10.1038/sj.bjp.070620 9.
46. Yamamoto T, Takahashi Y, Takagawa S, et al. Animal model of sclerotic skin. II. Bleomycin induced scleroderma in genetically mast cell deficient WBB6F1-W/W(V) mice. J Rheumatol 1999; 26(12): 2628-2634.

47. Willenborg S, Eckes B, Brinckmann J, et al. Genetic ablation of mast cells redefines the role of mast cells in skin wound healing and bleomycininduced fibrosis. J Invest Dermatol 2014; 134(7): 2005-2015. doi: 10.1038/jid.2014.12.

48. Dörner T, Lipsky PE. Beyond pan-B-cell-directed therapy - New avenues and insights into the pathogenesis of SLE. Nat Rev Rheumatol 2016; 12(11): 645-657. doi: 10.1038/nrrheum.2016.158.

49. Yanaba K. Strategy for treatment of fibrosis in systemic sclerosis: Present and future. J Dermatol 2016; 43(1): 46-55. doi: 10.1111/1346-8138.1302 6.

50. Singh J, Shah R, Singh D. Targeting mast cells: Uncovering prolific therapeutic role in myriad diseases. Int Immunopharmacol. 2016; 40: 362-384. doi: 10.1016/j.intimp.2016.09.019. 